\title{
Kabanti Kaluku Panda: An Ecofeminist Perspective in Local Wisdom
}

\author{
Kosilah $^{1}$, S Hafidhawati Andarias ${ }^{1}$, Arya Maulana Wijaya ${ }^{1 *}$ \\ ${ }^{I}$ Faculty of Teaching and Education, University of Muhammadiyah Buton, BauBau, Indonesia \\ "Corresponding author. Email: andy.arya@umbuton.ac.id
}

\begin{abstract}
Study of ecofeminism in local wisdom, especially in the indigenous people is relevant for this time. Buton has literary works of Kaluku Panda Atuwu Incana Dempa, to provide direction for social life based on environmental values and Islamic teachings. This study tries to identify of the suitability of the perspective of ecofeminism in the script of Kabanthi Kaluku Panda. Based on the study in this article explains that ecofeminism has its scope of knowledge in local wisdom, especially in the philosophy of society in an area. Therefore, in an effort to understand the relationship between feminist and ecological issues in literary texts, conceptually laden will be influenced by symbolic and linguistic relationships.
\end{abstract}

Keywords: ecofeminism, Kabanthi Kaluku Panda, gender

\section{INTRODUCTION}

In the last three decades, the study of ecofeminism refers to an analysis of ecofeminism concerning the relationship between racism, sexism, classicism, colonialism, speciesism and the environment [1]. However, on this site, there is still much that needs to be done in providing a study on this theme because the environment and culture will also influence how ecofeminism is translated, actualized and understood by the public. Gaard [2], also provides another way in the context of feminist ecocritical culture, as well as examining literary texts that must be done in building that understanding. For him, the meaning and practice of activism, as well as the best rhetorical strategy, would be suitable for developing and communicating in an ecofeminism perspective in a particular cultural context. Likewise [3] study of Taiwan culture that there is a feminist ecocritical perspective on Taiwanese literature and culture. The linkage of issues between culture and ecofeminism can be traced through many cultural works of a region. One of the ethnic groups in the archipelago that has a tradition of writing is the Buton area [4]. Like Buton culture, which has a wealth of past culture in the form of philosophy, culture, and written literature associated with the interpretation of ecofeminism as a theory. Likewise, in the chapter of the penultimate book, Environmental Culture: The Ecological Crisis of Reason, Val Plumwood, an ecofeminist philosopher who explores the alienation of location attachment to modern culture, which he calls "mobility will influence modernity," that cultural product can be part of the global study, which in this article deals with the study of ecofeminism [5].

It should be recognized that buton culture has many relics of old manuscripts written in several languages namely Malay, Arabic, Wolio [6]. This study puts forward analysis through text, one of the relevant texts in this study is the
Kabanthi Manuscript. The texts are full of messages about the values of life. One of them is Kaluku Panda Atuwu Incana Dempa, which is owned by the Buton people to provide direction for social life based on moral values and Islamic teachings. The purpose of this research is to develop ecofeminism and local culture perspective through Kabanthi text analysis, then this can be a new study in the study of ecofeminism, gender and understanding of the local culture of the Buton community.

As part of the study of feminism that began its discourse on the view that inequality in the treatment obtained by women and to fight for injustice that occurs in women. This study then develops on the theory of ecofeminism which represents such anxiety and bases its thought patterns on the relation of the roles of women and nature. Observing many ecofeminism phenomena then this study was conducted, with a focus on studies through the influence of Buton culture represented in the Kabati Kaluku Panda Manuscript, which is believed to be a morality rule on the relations of women and men in Buton society.

\section{METHOD}

The focus of this research is the study of the script of Kabanthi Kaluku Panda Atuwu Incana The quake written by La Ode Kobu (Yarona Labuandiri) consists of 70 stanzas. This research was conducted through the process of reading, listening and taking notes with the stages of a comprehensive reading of the text. While the value of ecofeminism is interpreted through critical analysis on each line of Kaluku Panda kabanthi, which is then analyzed using interactive analysis using gender indicators in the text message. This approach uses a different point of view in understanding the problem of ecofeminism in the kabanti kaluku panda script from a perspective that tends to be masculine and analogical. This approach is a cluster of critical research methods [7]. 


\section{RESULTS AND DISCUSSION}

\subsection{Local Genius as A Ecofeminism Approach}

Each community group in an area certainly has a pearl of local wisdom that is born from a series of interactions with nature, then forms a knowledge that is used for generations. But along with the development of modern knowledge, there is no need to get rid of local knowledge. In various scientific studies, the choice to change behavior is oriented towards traditional local culture.

According to The World Conservation Union [8] that around 6000 cultures in the world, there are around 5,000 of them or around $80 \%$ are indigenous people who see themselves, nature and relations between them from a religious perspective. Nature is understood as a sacred and holy thing. There is a harmonious relationship between humans and nature. There is a belief that the spiritual is one with the material. Harmony and balance are understood as the most important principles or values in the cosmic order. Ecofeminism is often translated as a study of injustice. But through the concept of justice that reduces the meaning of ecofeminism. On the other hand, understanding ecofeminism is not only through power relations between women and men in their social environment but also what it is like to build an understanding of these relations in the culture of society. Like Isshiki [9] which states that ecological awareness wants to see the reality of the world in an integrally holistic way, that the one world turns out to contain a lot of diversity.

Regarding this, an ecofeminist Karen J Warren [10], said that the connection is not surprising given that our society is formed by values, beliefs, education, behavior using a patriarchal framework, where there is a justification of the relationship of domination and subordination, suppression of women by men. Connectedness feminism and the environment cannot be separated from the similarity of the situation and the position of women and nature are always oppressed by patriarchal power[11]. Women and nature always have interesting studies to understand human social life. Tong[12] argues that there is a conceptual, symbolic and linguistic relationship between feminists and ecological issues.

In general, Buton people are known through local values which are called sabangka sarope values (friends of one boat), which in their practical scope are the basis of social ethics, interaction, and reciprocity by the community [13]. Whereas in written culture, Buton people have poems called kabanthi. This poem is then trusted by the Buton community as a means of conveying to the Buton community in terms of values, norms, and ethics of social life. Likewise, then these poems are used to illustrate the power relations between women and men in the structure of Buton society.

\subsection{Ecofeminism Perspective Butonese Society in Kabanti}

One of the famous literary works of the Buton region is Kabanthi kaluku panda atuwu incana dempa or better known as kaluku panda. The manuscript of La Ode Kobu (Yarona Labuandiri) consists of 70 stanzas where each stanza consists of four lines. The language used in the Kabanthi script is Wolio and Wolio. Kabanthi manuscripts are literary works consisting of some short sentences, do not contain rhymes, and are presented through songs and each sentence has wisdom and a message of morality in it[14].

Table 1 Typology Of Relationships Domination In Ecofeminism Discourse On The Kabanti Manuscript Kaluku Panda

\begin{tabular}{|c|c|c|}
\hline Manuscripts & Translated & Meaning \\
\hline Miyarangamu aasikeyampuu & For your neighbor humans love them & A mindset based on hierarchical \\
\hline Simbouduka maasiaka karomu & It's like loving yourself & values, namely the mindset of \\
\hline Ositumo wine inda momabongko & Thus the seed is never damaged & "top-down" which gives higher \\
\hline Tokaindeana naile muri-murina & For tomorrow's nursery tomorrow & $\begin{array}{l}\text { value, status or prestige to one } \\
\text { party. }\end{array}$ \\
\hline Kabubusina zikiri tetakbiru & Water also with dhikr and takbir fertilizer & dualism \\
\hline Perawaina khaluwati teetoba & Correct him by making love and atoning for sins & example, different pairs who are \\
\hline Adadiaka penembulamu siytu & When your land has grown, & seen as opposition and exclusive \\
\hline Ositumo penembula yipiyara & That's a plant that needs to be maintained & rather than sharing. \\
\hline Kalimbunguna anamisimo isyqi & The young coconut gives a sense of fun & The logic of domination, namely \\
\hline Momatu'ana kawondo ni'mati & His old coconut spreads deliciously fragrant & the structure of argumentation that \\
\hline Osiytumo tandaina rahmati & Thus it is a sign of mercy & leads to the justification of \\
\hline Kalabiana wine inciyasiytu & The advantages of such seeds & subordination. \\
\hline
\end{tabular}

From: Analysis dan Modified from Dominance relations by Karen J. Warren [9].

The Kabanthi kaluku panda manuscript has several copies and versions, but the manuscript that is referred to in this article is the Indonesian translation manuscript. In terms of language, my panda atuwu incana earthquake means a small coconut tree that grows on a rock. In general, this text discusses the teachings of the Butonese community in representing the concept of building a family that refers to the teachings of Islam as much as the majority religion of the Butonese community.

In 70 verses this Kabanti manuscript can be divided into several teaching concepts, including 1) the Concept of God, which includes 17 stanzas, 2) The Concept of Social Life 
covers 28 stanzas, and 3) The concept of building a family includes 25 stanzas. Besides, this text provides a description of the relationship between women and men in power relations but is described in concepts relating to nature or the meaning of farming in Buton society.

For this reason, the concepts described in this text are considered to correlate with theoretical definitions of ecofeminism. Similarly, who also helped define women are always associated with nature, so conceptually, symbolically, and linguistically there is a link between feminism and ecology issues [15]. For example, in many traditions of Indonesian people, the mention of the motherland (earth) is often attached to the motherland (femininity).

Whereas in understanding each part of this text, it shows that the description of the relation of women in the social life of the Buton community, is inseparable from the social or cultural environment of the local community and the concept of the gods of the majority of the Buton community, namely Islam. This gives an illustration that the true concept is written in this Kabanti script is a unified whole but has phases of life that start from the concept of God described in social relations, then ends in understanding the concept of family as the smallest social environment.

Like a literary work, the script of the panda emphasizes more on the analogy in explaining its meaning. For example, in the use of environmental analogies and natural phenomena as a system of social relations, and the process of farming as a message in carrying out the household process, especially in terms of wanting to create a good and dignified generation, in harmony with the identity of this nation. For this reason, this is in line with the assumption that eco-feminists believe that women have a closeness to nature to lead them to survive and protect, so it is not uncommon for women to be analogous to nature [5], [15][17][18] .

In general, in Table 1, that to understand the meaning of the Kaluku Panda Kabanti script leads to the concept of household Buton. The process starts from the preparation, selection, procession of marriage to the concept of sex in a relationship after marriage into a concept of value that is very valuable for the creation of a good generation. It's just that, referring to the analogy in each sentence indicates an unequal gender relation, where women are only perceived as passive objects. This is clearly illustrated in the function of women in reproduction interpreted as the process of farming. Interaction in relations between women and men is interrelated to four things namely ecology, production, reproduction, and awareness[9].

In the 3 verses described in Table 1, it is enough to then represent the values contained in the kabanti kaluku panda script. Besides, gender as a representation of meaning in the text is related to the existence of women as the meaning of production and reproduction. The relation of dominance in the text describes an indication of a strong, hierarchical, dualistic and oppressive mode of patriarchal thinking. So then it is difficult to find a narrative that can explain that gender equality occurs in the text.

However, gender relations, in this case, the role of women to be interpreted in the Kabanti is the script of the panda. Not only understood as a form of morality rules but also able to describe the concept of a more patriarchal culture.
This can explain that ecofeminism, has its scope of knowledge in local wisdom, especially in the philosophy of the community in an area. Therefore, to understand the relationship between feminist and ecological issues in literary texts, conceptually laden will be influenced by symbolic and linguistic relationships.

\section{CONCLUSION}

The study of ecofeminism in the Kabanti if I panda the script by the Butonese community is under patriarchal relations in social relations. This is not surprising given that local communities are generally shaped by values, beliefs, education, behavior that define the patriarchal framework, which must be understood in terms of domination and subordination.

In general, the text can be interpreted in three main frameworks of gender relations in the 70 standards in it, namely the concept of God, social relations and the concept of building a family. But in fact, the relationship provides information on the existence of a hierarchical mindset, dualism of values and the logic of dominance that is depicted in the relations of relations between women and men in the analogy of farming. So this study understands that feminism and ecological discourse will greatly influence the culture that is believed by the local community.

\section{ACKNOWLEDGMENT}

\section{Thank you for Universitas Muhammadiyah Buton to support this research.}

\section{REFERENCES}

[1] G. Gaard, "Ecofeminism revisited: Rejecting essentialism and re-placing species in material feminist environmentalism," Fem. Form., vol. 23(2), pp. 26-53, 2011.

[2] G. Gaard, "New directions for ecofeminism: Toward more feminist ecocriticism," ISLE Interdiscip. Stud. Lit. Environ., vol. 17(4), pp. 643-665, 2010.

[3] C. Chang, "Putting Back the Animals: Woman Animal Meme in Contemporary Taiwanese Ecofeminist Imagination," Chinese Ecocinema Age Environ. Chall., 2009.

[4] T. Pudjiastuti, "Prosiding Simposium Internasional IX Pernaskahan Nusantara di Kota Baubau," in Naskah Buton yang Mengesankan, 2009.

[5] V. Plumwood, Environmental culture: The ecological crisis of reason. Routledge, 2005. 
[13] A. A. M. Wijaya, "Modal Sosial Untuk Kapasitas Community Governance (Studi Kasus Perempuan Pesisir Kelurahan Sulaa Kota Baubau),” J. Ilmu Pemerintah. Kaji. Ilmu Pemerintah. dan Polit. Drh., vol. 1, no. 1, p. 107, 2016.

[14] Y. Darmawan, Naskah Buton, Naskah Dunia. Baubau: Respect, 2009.

[15] D. Susilo and A. Kodir, "Politik Tubuh Perempuan: Bumi, Kuasa, dan Perlawanan,” J. Polit., vol. 1, no. 2, 2016.

[16] M. E. Zimmerman, Contesting Earth's Future: Radical Ecology and Postmodernity. Berkeley: University of California Press, 1994.

[17] J. Seager, Earth Follies: Feminism, Politics and the Environment. London: Earthscan Publication, 1993.

[18] Wiyatmi, Kritik Sastra Feminis: Teori dan Aplikasinya dalam Sastra Indonesia. Yogyakarta: Penerbit Ombak, 2012.
[12] R. P. Tong, Feminist Thougt: Pengantar Paling Komprehensif kepada Aliran Utama Pemikiran Feminis. Yogyakarta: Jalasutra, 2010. 